\title{
Perspectives on the Guaranteed Income, Part II
}

\author{
Karl Widerquist \\ Staff Economist, The Educational Priorities Panel, 225 Broadway, Suite 3101, New \\ York, NY 10007, Karl@Widerquist.com
}




\section{Perspectives on the Guaranteed Income, Part II}

A review of nine books on the guaranteed income:

Ackerman, Bruce and Anne Alstott 1999. The Stakeholder Society. New Haven: Yale University Press.

Fitzpatrick, Tony 1999. Freedom and Security: An Introduction to the Basic Income Debate. St. Martin's Press, Inc. 234 pages.

George, Robley E. 2000. Socioeconomic Democracy: An Advanced Socioeconomic System. Manhattan Beach, CA: Center for the Study of Democratic Societies. 298 pages.

Groot, Loek and Robert Jan van der Veen (eds.), 2001. Basic Income on the Agenda: Policy Objectives and Political Chances. Amsterdam: Amsterdam University Press.

Jordan, Bill, Phil Agulnik, Duncan Burbidge, and Stuart Duffin, 2000. Stumbling Towards Basic Income: The Politics for tax-benefit integration. London: The Citizens' Income Study Centre.

Lerner, Sally Charles M. A. Clark, and W. Robert Needham. 1999. Basic Income: Economic Security for All Canadians. Toronto: Between the Lines. 120 pages.

Rogers, Joel and Joshua Cohen (eds.) 2001. What's Wrong with a Free Lunch? Boston: Beacon Press

Shafarman, Steve 2000. Healing Politics: Citizen Policies and the Pursuit of Happiness. Xlibris.

"Perspectives on the Guaranteed Income, Part 1" (Widerquist 2001) reviewed six English-language books on the guaranteed income that were released between 1990 and 1998. More books have been released on this topic in the three years since work on part one began than in the pervious eight-clearly interest in the guaranteed income is accelerating, and it is already time for a part two.

The guaranteed income (also known as the basic income guarantee) is the unconditional assurance that no one's income falls below a certain level for any reason. There are many ways to accomplish this goal, but much of the recent literature focuses on a version called the basic income (BI or UBI), which is an income paid by the government to every citizen regardless of private income, wealth, employment, or marital status. It rewards people for earning more at all levels of income, while ensuring no one is destitute. Most citizens will be net taxpayers, but the permanent, universal nature of the grant is structured so that all individuals can count on a guaranteed minimum. Charles Clark (1997) estimates that a flat tax of 36 percent could support all existing government 
spending and a BI of just under $\$ 8000$ for each adult and $\$ 2000$ for each child. The nine books discussed below consider a wide range of proposals for different kinds of income guarantee.

Several other recent books include a discussion of the guaranteed income but are not reviewed here because it is not their main focus. These include Aronowitz and Cutler (1998) Post Work, André Gorz (2000) Reclaiming Work, Guy Standing (1999) Global Labor Flexibility: Seeking Distributive Justice, Michael W. Howard (2000) SelfManagement and the Crisis of Socialism, and Alice O'Connor (2001) Poverty Knowledge: Social Science, Social Policy, and the Poor in Twentieth Century U.S. History.

Freedom and Security: An Introduction to the Basic Income Debate.

Fitzpatrick, Tony 1999. St. Martin's Press

This book is a very concise and well-written introduction to the philosophical debate over basic income. However it is not so much "an introduction to the basic income debate" as it is a discussion of how basic income could be incorporated into many of the ideological debates going on today.

Chapter one contains a short history. Chapter two discusses the current social benefit system in Britain. Chapter three gives a 13-page description of basic income. Chapter 4 discusses the case for and against basic income. Part 2 relates basic income to various ideological debates. Chapter 5 discusses the radical right's case against the present social insurance system and for a negative income tax (NIT). Of course, many on the radical right today prefer a complete dismantling of the welfare system without replacing it with anything, but it is the negative income tax idea the Fitzpatrick focuses on. Fitzpatrick makes more out of the difference between the two than most authors. Although he is aware that the same after tax income distribution can be achieved with either policy, he would only support a basic income. A large reason for this seems to be guilt by association. The NIT was once popular with the radical right and therefore it must be bad. Another reason is that the NIT is given after the fact and can leave individuals in a distressing situation between receiving their last paycheck and their first NIT check, while the universal nature of basic income gives more solid security.

Chapter 6 relates basic income to what Fitzpatrick calls, "welfare collectivism," or the ideology behind the current social welfare system. Basic income four features that make it appealing to this ideology. It reaches people that the current system lets fall through the cracks; it reduces the poverty trap; it simplifies the tax and benefit system; and it allows worker flexibility without sacrificing the worker's income level. However, the disadvantage from this prospective is that basic income does not demand a reciprocal obligation on the part of recipients. In responses, Fitzpatrick suggests that participation income as proposed by Tony Atkinson (1996) might be appealing from this perspective. A participation income is essentially a basic income for 
all those who meet certain conditions for "participation" in society such as working, raising children, or volunteering.

Chapter 7 relates basic income to socialist ideology; chapter 8 relates it to feminism; and chapter 9 relates it to environmentalism. Fitzpatrick shows basic income has features that could appeal to these ideologies. The weakest feature of the book is that he does not try to unify these separate debates into the basic income debate. He seems content to let basic income be different things to different people. To the welfare collectivist or the libertarian basic income decreases wages because workers would no longer have to rely upon wages for a livable income, but to the socialist a basic income increases wages by giving workers greater bargaining power. It cannot simultaneously do both, but Fitzpatrick does not attempt to say which it will do.

\section{Basic Income: Economic Security for All Canadians.}

Sally Lerner, Charles M. A. Clark, and W. Robert Needham. 1999.

This book is a short, easy-to-read political pamphlet that describes what basic income is, how it works, and how it is justified, but it only a very brief introduction. The discussion applies specifically to Canada, but the basics lessons of the book are transferable to any industrialized country. The authors argue that basic income is the natural response the realities of the current economic situation. The old assumptions (that the economy provides good-paying jobs for everyone who wants one and that the government need only provide for those who are unable to work or who are temporarily unemployed) are simply not true any more. They describe an economy in which even the better paying jobs are increasingly insecure and in which more and more jobs are in the low-paying service sector. However, these are issues of how that wealth is being distributed; there is as much or more wealth in the economy today as ever before. A basic income could fill in the gaps in the security created by the new economy. It can provide a permanent boost to low-wage laborers and a springboard for others.

The authors review the history of the guaranteed income in Canada, which came close to becoming a reality in the 1930s, and they discuss the recent decline in Canada's commitment to economic security. One thing that makes this book different than the others is that it includes some hard estimates of the costs of a basic income. They estimate a flat tax of just over $41 \%$ could support all government spending plus a basic income large enough to virtually eliminate poverty in Canada.

The authors believe the connection between the more "flexible" economy and basic income could become an important argument for BI. If "flexibility" is a real need of modern business and not a euphemism for low wages and insecure employment a basic income can emerge as a sensible strategy. Basic Income may be the only policy that can allow employers to have their flexibility without threatening the livelihood of workers.

\section{The Stakeholder Society}


This book proposes that the government grant a "stake" of $\$ 80,000$ to every U.S. citizen in four yearly installments beginning on their twenty-first birthday providing that they have graduated from high school and have not been convicted of a crime. This "stake" is to be funded by a 2 percent tax on wealth and eventually by the repayment of the stake (plus interest) out of the estate of recipients. This proposal has gotten onto the political agenda already; British Prime Minister Tony Blair cited it as part of the inspiration for his recent proposal for a much smaller "baby bond."

"Stakeholding is quite different from most BI proposals, which would pay small amounts in weekly or monthly installments throughout a person's life, but it is an income paid to all citizens without a means test or work requirement and therefore (as the authors mention) it is a form of basic income. In fact, the authors point out that unless rules are made to prevent borrowing against a basic income the two are identical. One could convert an $\$ 80,000$, one-time grant into a $\$ 4,000$ annual annuity and one could borrow $\$ 80,000$ against a $\$ 4,000$ basic income. However, the government could prevent people from borrowing against a basic income and thus, there is a substantive difference between the two that needs to be considered.

The goal of most basic income proposals is to achieve a minimum level of equality of outcome; the goal of Stakeholding is to achieve a minimum level of equality of opportunity. As the authors put it, "Stakeholding is not a poverty policy; it is a citizenship policy." They believe Stakeholding will make everyone feel that their society gave them a real chance that is not otherwise available to a majority of people, and that it will greatly reduce inequality and increase economic mobility within society.

The authors are aware that some people will squander their stakes and that the existence of stakeholder grants could make it more difficult for such people to get help, but they reply (p. 215), "You have a chance, once in your life, to step up to the plate. If you plan ahead and act sensibly, you may win big. But if you mess up, you live with the consequences. The basic income cushions failure; Stakeholding is a launching pad for success." Yet, they don't mention that cushioning failure promotes equality of opportunity as well. If you want a trapeze artist to do bigger jumps should you give her better trapeze equipment or a net?

Ackerman and Alstott criticize Social Security privatization plans for subjecting retirement to market luck, but underplay the role of luck in determining which Stakeholders succeed and fail. Although economic insecurity is a significant drawback to the Stakeholding proposal the authors claims that it will greatly reduce inequality and increase economic mobility are undoubtedly true, and I must admit that I am much more sympathetic to this proposal than I was before reading this book.

Socioeconomic Democracy: An Advanced Socioeconomic System.

Robley E. George, 2000 
This book defines "Socioeconomic Democracy" as, "A model socioeconomic system in which there is some form of Universal Guaranteed Personal Income as well as some form of Maximum Allowable Personal Wealth, with both the lower bound on personal material poverty and the upper bound on personal material wealth set and adjusted democratically." The book wanders off on too many tangents to make a solid for these two policies, but these tangents are the most interesting parts of the book. At its best this book reads of Heilbronner's The Worldly Philosophers or Teachings from the Worldly Philosophy, with extended quotes and detailed bibliographic information about people as diverse as Huey Long, Thomas Jefferson, and Muhammad. But these interesting quotes do not add up to a sound case for the policies George proposes and do not make the book what it claims to be: an advanced textbook in "Socioeconomics."

In short, the reader will probably not find that the book adequately addresses any reservations might have about either of the two limits proposed by George. The best way for George to bring attention to Socioeconomic Demoncracy would be to put it aside for one book and write something about the history of inequality. Such a book would give him the opportunity to do use his biographies, his storytelling, and his extended quotes in a relevant setting and would probably be well received. Then, after he has everyone's attention, he can make a more rigorous argument for "Socioeconomic Democracy."

\section{Stumbling Towards Basic Income: The politics for tax-benefit integration.}

Jordan, Bill, Phil Agulnik, Duncan Burbidge, and Stuart Duffin, 2000.

This book discusses basic income in the context of the current social policy debate in the British parliament. It includes a survey of opinion on the issue among members of parliament. Just the fact that there are any recognized supporters in parliament demonstrates that it is much more on the agenda there than in the United States, but a big jump to a full basic income is likely to fail because opponents tend to be insiders with the power to keep it off the agenda for now.

The basic argument of the book is that there has been a change in the political culture in Britain and Ireland that reflects a breakdown in the old political consensus on the role of social security. The government is set on a course toward revising the public finance system to ensure that "it pays to work." The authors believe that the government's central values will eventually be compromised by the overriding priority given to paid work, and the attempt to restrict benefits to those who are judged to be in genuine need. At that point, basic income could become a viable political alternative. The authors suggest a gradual process of creating some conditional income guarantee (such as labor market participation) and then broadening the conditions (along the lines of a participation income proposed by Atkinson 1996), eventually leading to an unconditional basic income.

The authors are no doubt aware that there is a bit of wishful thinking in this prediction. Whether we move gradually toward universality or do it all in one shot, the hard part is convincing people to take the step from conditional to unconditional. If they 
really don't want to take that step, they will not stumble over it. As the authors are aware, there is a danger in the gradualist approach. Many of the steps towards BI have poverty traps, work disincentives, or administrative costs that basic income does not have. If we adopt a gradualist policy, people could see these shortcomings as a reason to move further towards a basic income or they could see them as evidence that we should stop moving in that direction.

Healing Politics: Citizen Policies and the Pursuit of Happiness.

Steve Shafarman, 2000.

This book is designed to build a movement for two "Citizen Policies:" "Citizen Dividends" and "Citizen Service." "Citizens Dividends" is his name for a basic income guarantee. "Citizen Service" is the government mandated-but not enforcedobligation for all citizens to perform eight hours per month of service to the community. Shafarman argues that everyone would be happier in a healthier society without the extremes of deprivation that eixst today and with a feeling that we have all contributed to making our society into a better place.

Shafarman's reasoning turns the incentive compatibility arguments of mainstream economics on their head: instead of creating policies that are compatible with narrow individual self-interest, individuals need to be convinced that their own selfinterest is not so narrow. Mainstream economics with its strict adherence to maintaining ignorance of the process of preference formation, can neither support nor oppose such a claim. Of course, how to bring people around to that belief is the hard part.

If Citizen Service were an enforced obligation, it would largely silence those who believe workers will resent nonworking recipients, but it is not enforced in shafarman's program. He argues that it is not worth the trouble to enforce the obligation, that it is not up to any of us to judge the value of another's contribution, and that those who have no other income aside from the Citizen Dividends will feel a stronger moral obligation to perform their service than anyone else. However, recall the persistent myth of the welfare mother who drives a Cadillac that proved so strong despite the reality of welfare recipients who are in a struggle to pay for both rent and food. It is quite possible that a similar myth about nonworking recipients will arise even if most perform more Citizen Service than anyone else. If so, the unenforced obligation might increase the problem of worker resentment of nonworkers.

Basic Income on the Agenda: Policy Objectives and Political Chances.

Groot, Loek and Robert Jan van der Veen (eds.), 2001.

Most of the articles in this edited volume were presented at the Seventh International Congress of the Basic Income European Network (BIEN) in Amsterdam in September 1998. The book presents itself as the sequel to Arguing for Basic Income, 
Edited by Philippe Van Parijs (1992), which contained articles from an earlier BIEN Congress.

Part One examines the short-term policy objectives of basic income supporters who hope to get the idea on the agenda of mainstream European politics. Paul de Beer argues that basic income could be the double-edged sword that could cut through the perceived tradeoff between high poverty and high unemployment. Philippe Van Parijs, Laurence Jacquet, and Claudio Caesar Salinas compare a partial basic income to other policies to find the most politically appealing step towards a full basic income. Frank Vandenbrouke and Tom Van Puyenbroek discuss whether basic income can be made consistent with the normative belief that people have a social responsibility to contribute. Ingrid Robeyns discusses the relationship between basic income and feminism. Anton Hemerijck discusses basic income in the context of society with a diminishing need for human labor. Fritz W. Sharpf does not find ethical arguments put forth by basic income supporters to be saleable in the current political environment and opts in the short run for proposals that will improve work opportunities. Steve Quilley puts forward what seems to be the consensus opinion that a small participation income (Tony Atkinson 1996) based on eco-taxes (such as pollution taxes) could become feasible in the European Union in the near future.

Part Two discusses the recent history of the basic income movement in the Netherlands, Sweden, Finland, Ireland, Germany, Denmark, France, and Belgium. Although at one time or another BI has been discussed in mainstream politics in each of these countries it can only be said to really be on the agenda in Ireland and Finland, and it still faces significant hurdles there. All in all, the tone of the book is rather pessimistic. Much of it revolves around what piecemeal implementation can lead to a basic income without encountering steep opposition; Even Van Parijs, who elsewhere has promoted the highest sustainable basic income, admits that in the short run, BI may need to step aside in favor of the Earned Income Tax Credit or a Participation Income.

\section{Daily Bread, the Story of Jasper's Box}

Stephen C. Clark, 2001

Unlike the other books reviewed here, this is a work of fiction, but it belongs in this review essay because its purpose is much the same as the others: to make a case for a specific basic income proposal. The book proposes a large daily basic income financed by a large but steady and predictable increase in the money supply. It also contains a love story, action, and intrigue as any popular novel. I am no literary critic and I will not attempt to review these aspects of the book. The part that concerns us is what kind of a case does it make for its BI and for Clark's method of financing it.

The book is set in the broccoli-growing region of California where an almost entirely Mexican workforce does some of the hardest work for some of the lowest pay in the United States. Mysterious bank machines suddenly appear giving $\$ 100$ a day to anyone who asks for it. This amount of money means so much to farm workers that 
nearly all of them leave their jobs immediately amid allegations of laziness by better-paid workers who remain at their jobs. But in a matter of days growers are forced by the pressure of harvest time to entice the workers back with better pay, better working conditions, and a share of the profits. While it makes a good case that basic income can help low-wage workers, the book lacks a good description of just how bad the poverty is of farm workers in California today. The author seems to assume that everyone knows just what life is like for migrant farm workers.

The weakest part of the book (and presumably most difficult to dramatize) is Clark's case for the financing of his basic income. Within the last few pages he squeezes in assertions that a basic income can be financed solely by money creation, that banks should not be allowed to create money, and that a steady increase in the money supply will smooth out the business cycle. With the space he gives it, there is not enough time to explain how all of this is supposed to work much less to make a convincing case that it will work.

\section{What's Wrong with a Free Lunch?}

Joel Rogers and Joshua Cohen (eds.) with its central article by Philippe Van Parijs

Philippe Van Parijs's two previous books on basic income-Real Freedom for All, and Arguing for Basic Income (Van Parijs 1992, 1995)_-were reviewed in the first article (Widerquist 2001). He brings his advocacy to the United States as the central author in this edited volume by Rogers and Cohen. Van Parijs makes argues for a subsistence level unconditional basic income (UBI) as a policy for justice, labor, feminism, and the environment. His justice case for a basic income is that society should grant its least-advantaged citizen as much real freedom as possible by granting a UBI. As a labor issue, UBI is a practical program to deal with an increasingly uncertain labor market. As a feminist issue, UBI rewards women for non-labor-market work that they are much more likely to choose than men and it makes them less financially dependent on men. As a Green issue, UBI opens up alternatives to simpler more environmentally friendly lifestyles.

Eight authors give full support to the program. The late Nobel Laureate, Herbert Simon argues that an income tax of up to 70 percent would tax only the portion of a person's income that comes from productivity advances that they had nothing to do with and would leave their individual incentive to work largely, if not fully, in place. Ronald Dore sees a subsistence-level UBI as a transitional step towards a higher basic income in the future, but Brian Barry argues that UBI should be limited to subsistencelevel. Robert E. Goodin supports the UBI on the pragmatic grounds that there are too many different reasons for poverty in the complex, modern economy for a categorical welfare system to have any realistic hope of success. Gar Alperovitz supports UBI because it provides the essential basis for independence, and without it, a worker is financially dependent on employment for survival. He sees universal stock ownership as the best means to support a basic income. 
Anne L. Alstott (coauthor of The Stakeholder Society) supports UBI on the grounds that it breaks the link between welfare benefits and paid work and thus would break the gender gap in the U.S. welfare state. According to Alstott, a UBI of only half what Van Parijs is proposing would increase the income of the median single woman by 18 percent and increase in the income for the median elderly woman by 40 percent. Katherine McFate makes another feminist case for UBI: Prevailing doctrine, as she sees it, holds that poor children are better off if their mothers are employed outside the home, while someone else looks after their children, but nonpoor children are better off if their mothers forego earned income to become full-time caregivers.

Claus Offe supports the UBI and suggests three gradualist strategies all designed to ally people's fears that UBI will undermine work incentives. First, Tony Atkinson's (1996) participation income would create a basic income conditional on people taking part of some list of acceptable activities, including paid work or unpaid care or volunteer work. Second, UBI could begin at a level that was too low for people to live on, but still make a substantial impact on the incomes of the working poor. Third, Offe's own proposal for a "sabbatical account" would essentially create a temporary UBI. This proposal would have many of the benefits of a UBI without creating conditions that would allow people to live permanently without paid work.

Four authors lend qualified support to Van Parijs's proposal. Both Wade Rathke and Peter Edelman, though sympathetic to the idea, worry that attention to UBI will distract attention from more politically salient ideas that stand a better chance of being enacted. Edelman sees UBI as a component of a renewed distribution system that has work as its centerpiece. Emma Rothschild finds UBI appealing for the affect it will have on equality and political inclusion within one nation, but worries that it could make the differences between nations more striking. Fred Block supports the idea some form of basic income guarantee but suggests that it could be more efficiently granted in the form of a negative income tax.

Only three of the 17 authors come down as solid critics of the proposal. William A. Galston cites the principle of reciprocity - that people who receive something should give something back. Elizabeth Anderson criticizes UBI because she believes it "promotes freedom without responsibility, and thereby both offends and undermines the ideal of social obligation that undergirds the welfare state." Edmund Phelps criticizes UBI in favor of a plan for subsidized wages outlined in detail in his book Rewarding Work (1997). He believes that individuals have the obligation to contribute to society in exchange for the benefits they receive, and that work confers practical benefits on workers that can't be gained from a UBI. Although Phelps is an economist, he ignores a cardinal rule of the discipline, that the individual is the best judge of his own needs, saying "We should feel sorry, not envious, about (someone who does not work under a UBI program), he doesn't know what he's missing." Phelps apparently believes that in this one instance individuals are not capable of judging what is best for them, but that social scientists can decide better how to maximize an individual's utility than the individuals themselves. 


\section{Conclusion}

These are wide range of books from purely academic to the grass roots. Most agree that basic income is currently far out of the U.S. political mainstream, but it may not always be so. The civil rights movement was far out of the political mainstream in 1950; Social Security wasn't even thought of in 1920; abolition was wildly radical in 1850. The guaranteed quickly appeared in the U.S. political mainstream in the 1960s and as quickly disappeared in the 1970s. But how to get the idea into serious consideration is a difficult question. As Fitzpatrick (1999) observes, UBI has the potential to have wide appeal as a solution to obvious deficiencies in today's work-based welfare system. It has features that make it appealing to across the ideological spectrum, and features that make it suspect across the political spectrum. The right can demonize it as radical and the left can demonize it as reactionary. It can appeal to the left as an effort to give more freedom to the least advantaged, but it doesn't directly address the problem of access to jobs. It can appeal to the right as a simplified alternative to the still complex welfare state, but it may be seen as an affront to the work ethic. It can appeal to feminists because it will give individuals greater opportunity to perform unpaid care work, but it doesn't directly address the persistent problem of sexual discrimination in the workplace. Its ability to either appeal to or offend so many different political interests has kept it out of the political mainstream for the last twenty-five years, but the same ability could cause it to emerge rapidly as a compromise. The right is not likely to acquiesce to anything like UBI also long as the political tied is toward dismantling the welfare state, but if and when the tied turns towards rebuilding the social safety net, no one is likely to desire to rebuild it along the lines that were tired and discarded in the last 40 years. Therefore, the basic income guarantee could then emerge as a fresh policy worth of a trail.

To get to that point basic income supporters need to present the idea as a wellthought-out idea, and to increase public awareness of and concern for the persistence of poverty, and hopefully take small steps in that direction. Four of the above books (Groot and van der Veen 2001, Rodgers and Cohen 2001, Fitzpatrick 1999, and Jordan et al 2000) agree that a Participation Income (Atkinson 1996) is the most politically saleable gradualist approach. However, this may not be the best short-term strategy in the United States where the 1996 welfare reform turned away from the recognition of care work as a contribution to society. A participation income involves substantial supervision of recipients and so it can be as paternalist as the current welfare state while it is equally as complex and more expensive.

Perhaps, one piecemeal approach that may be politically saleable in the United States is a partial UBI based on collective ownership of natural resources. There seems to be great resistance in the United States to nonworkers who are "recipients" but not to nonworkers who are "owners." The Alaska Permanent Fund pays a small UBI to every Alaskan from the state's collective ownership of its oil resources, and it receives strong support throughout the income distribution. The Fund is not large enough to be thought of as a solution to poverty but it does make an important difference in the lives of people living near the margins while it is not even thought of as part of "the welfare system." If it continues to grow at the same rate that it has over the last 20 years (which is doubtful) 
it will be a viable solution to poverty in Alaska within another 20 years. But that fund was started with an unusual opportunity, when an asset that was widely viewed as being collectively owned was privatized. Privatization of state owned assets in the former communist countries and the sale of rights to the broadcast spectrum might have provided similar opportunities, but there was no organized constituency advocating such a policy. Perhaps basic income supporters should look for such opportunities in the future in hopes of creating Alaska-style funds in the United States and Europe. The gradually increasing value of such funds could give the least advantaged greater and greater flexibility while building a broad—if not universal—constituency that sees itself as the rightful owners of that fund. 


\section{References}

Aronowitz and Cutler, 1998. Post Work

Atkinson, Anthony B. 1996. "The Case for a Participation Income", in The Political Quarterly (Oxford) 67 (1), January-March 1996, 67-70. Clark, Stephen C. 2001. Daily Bread, the Story of Jasper's Box

Gorz, André, Reclaiming Work, Oxford: Blackwell, 2000.

O'Connor, Alice (2001) Poverty Knowledge: Social Science, Social Policy, and the Poor in Twentieth Century U.S. History.

Phelps, Edmund S. Rewarding Work. How to Restore Participation and Self-Support to Free Enterprise, Cambridge (Mass.): Harvard University Press, 1997, 197 p.

Standing, Guy 1999. Global Labor Flexibility: Seeking Distributive Justice. New York: St. Martin's Press, Inc.

Van Parijs, Philippe (ed.) 1992. Arguing for Basic Income: Ethical Foundations for a Radical Reform. New York: Verso.

Van Parijs, Philippe. 1995. Real Freedom for All: What (if anything) can justify capitalism? Oxford: Clarendon Press.

Widerquist, Karl 2001. "Perspective on the Guaranteed Income." The Journal of Economic Issues (September).

UBI can stand for universal or unconditional basic income.

Except redistributional programs that would be replaced by UBI.

He uses the term "ecologism."

A basic income could simultaneously raise after-tax-after-transfer wages for workers while lowering before-tax-before-transfer wages for employers, or it could raise wages for some occupations while reducing wages for others, but if this is what Fitzpatrick has in mind he does not say so.

That is, $\$ 7,000$ (Canadian) for each person 65 and over, $\$ 5,000$ for each person 21 to 64 , $\$ 3,000$ for each child, and an additional $\$ 5,000$ for each household regardless of size.

For the full length version of his justice case for UBI see Van Parijs 1995. 